\title{
Pornography consumption and non-marital sexual behaviour in a sample of young Indonesian university students
}

\section{Gert Martin Hald \& Teguh Wijaya Mulya}

To cite this article: Gert Martin Hald \& Teguh Wijaya Mulya (2013) Pornography consumption and non-marital sexual behaviour in a sample of young Indonesian university students, Culture, Health \& Sexuality, 15:8, 981-996, DOI: 10.1080/13691058.2013.802013

To link to this article: http://dx.doi.org/10.1080/13691058.2013.802013

曲 Published online: 20 Jun 2013.

Submit your article to this journal $₫$

Џll Article views: 319

Q View related articles $\longleftarrow$

Citing articles: 9 View citing articles 


\title{
Pornography consumption and non-marital sexual behaviour in a sample of young Indonesian university students
}

\author{
Gert Martin Hald ${ }^{\mathrm{a} *}$ and Teguh Wijaya Mulya ${ }^{\mathrm{b}}$ \\ ${ }^{a}$ Department of Public Health, Clinic of Sexology, Copenhagen University Hospital, University of \\ Copenhagen, Denmark; ${ }^{b}$ Faculty of Psychology, University of Surabaya, Indonesia
}

(Received 5 October 2012; final version received 30 April 2013)

\begin{abstract}
Using a sample of Indonesian university students and a cross sectional design, this study investigated prevalence rates and patterns of pornography consumption in Indonesia, a religious, sexually conservative, Muslim-majority nation with strict antipornography laws. Further, the association between pornography consumption and common non-marital sexual behaviours was explored. The study found that in this sample, pornography is as widely and readily consumed as in comparable international studies predominantly utilising Western background samples from more sexually liberal and less religious countries with very few laws on pornography. Gender differences in patterns of pornography consumption were pronounced and comparable with findings in international counterpart studies. For men only, pornography consumption was found to significantly predict common sexual behaviours in nonmarital relations. The study is the first to provide insights into prevalence rates and patterns of pornography consumption and its association with common non-marital sexual behaviours in a sexually conservative, Muslim-majority nation with strict antipornography laws.
\end{abstract}

Keywords: pornography; sexually explicit materials; sexual behaviour; Indonesia

\section{Introduction}

Is pornography as widely and readily consumed among university students in a religious, sexually conservative, Muslim-majority nation with strict anti-pornography laws as in the Western world? And is this consumption associated with common sexual behaviours in non-marital relationships over and above relevant control variables? We first provide a brief overview of sexuality and pornography in Indonesia. We then review existing literature on pornography consumption and its association with a variety of sexual behaviours. Finally, we outline the theoretical framework and aims of the study.

\section{Sexuality and pornography in Indonesia}

Indonesia has roughly 240 million inhabitants and is the world's most populous Muslimmajority nation, with approximately $90 \%$ of the population being Muslim (BPS-Statistics Indonesia 2010). Indonesian Muslims are diverse, ranging from liberal to conservative, with most being fairly moderate compared to Muslims in the Middle East (Houben 2003). Religion plays a big role in Indonesian society and everyday life and Indonesians are required to have their religious affiliation written on their national ID card (BPS-Statistics Indonesia 2010; Ministry of Religious Affairs 2005).

*Corresponding author. Email: gertmartinhald@gmail.com 
Sexuality in Indonesia is generally assumed to be conservative and sex is socially acceptable only within monogamous, heterosexual, religiously recognised marriages (President of the Republic of Indonesia 1974; Situmorang 2003). Cohabitation is not officially permitted by government or sanctioned by society (Bennett 2005a). Premarital sexual activities are sanctioned by society and considered to bring shame on the person and family involved, particularly if the individual concerned is female (Padang 2012).

Sexuality in Indonesia is enmeshed in religious (Bennett 2005b), cultural (Davies 2010; Jennaway 2003; Withers and Browner 2012), racial (Munro 2012), legal (Wieringa 2010), political (Wieringa 2000), educational (Utomo 1997) and health (Jacubowski 2008) discourses. Consequently, official political opinions, attitudes, policies and laws concerning sexuality are widely contested. For instance, Utomo and McDonald (2009) reported how the implementation of sexual and reproductive health policies in Indonesia in the last two decades have been struggling within the conflicting forces of traditional values, Westernisation and Islamic fundamentalism. Other examples may be found in the works of Blackwood (2007), Boellstorff (2007) and Wright-Webster (2008) which reveal the complex dynamics of sexual diversity beyond dominant heteronormative discourses in Indonesia.

The effects of socio-economic change, modernisation and globalisation among Indonesian youth have resulted in greater freedom and autonomy during the past two decades, presumably contributing to a more open and liberal expression of sexual identity, attitudes and behaviours (Harding 2008; Utomo 1997; Utomo and McDonald 2008). Nevertheless, young people's awareness of risky sexual behaviour related to sexually transmitted infections (STIs) and unwanted pregnancies is still relatively limited (Ford, Shaluhiyah, and Suryoputro 2007; Simon and Paxton 2004), presumably due to a strong prohibitive discourse among sexuality educators and religious leaders (Holzner and Oetomo 2004). This has given rise to recent studies focusing on sexual education and HIVprevention programmes (e.g. Diarsvitri et al. 2011).

Regarding pornography in Indonesia, scholars have paid considerable attention to the controversy of the anti-pornography law passed in 2008. This law prohibits Indonesians to 'produce, make, copy, distribute, broadcast, import, export, offer, trade, lease, provide, show, utilise, own, or save' pornography (President of the Republic of Indonesia 2008). Violation of the anti-pornography law carries sentences of between 6 months and 12 years of imprisonment. The anti-pornography law has been discussed extensively in the academic literature in relation to religious conservatism and gender activism (Allen 2007), legal process (Sherlock 2008) and human rights (Nilsson 2010).

Beside the anti-pornography law controversy, another strand of research on pornography in Indonesia has involved media analyses of pornographic videos and magazines (Kitley 2008). However, in-depth studies focusing on Indonesian youth engagement with pornography are few, problematic with regard to methodology and data analysis, not available in English and not published in peer-reviewed journals.

\section{Prevalence rates and patterns of pornography consumption}

With few exceptions (see also Wright 2013), international studies have reported consumption rates in the range of 50-99\% amongst men and 30-86\% amongst women (Hald et al. 2013). However, these rates have been found to be heavily influenced by sample characteristics (e.g. age), time period assessed (e.g. pornography consumption in the past six months, year, ever), definition of pornography and study methodology and 
design. In an Indonesian context, using a sample of 395 junior high school students, Supriati and Fikawati (2009) found that $83 \%$ of respondents had been exposed to pornography.

Compared to women, men have been found to use pornography more frequently, spend more time on pornography consumption, be exposed to pornography at a younger age, use pornography more often during masturbation (Hald 2006), prefer pornography with many different actors as compared to pornography with the same actors performing different acts, be more attracted to both a wider range of hardcore pornography and hardcore pornography devoid of relationship context and emotional attachments and generally be more sexually aroused by pornography (Chivers et al. 2010; Hald and Malamuth 2008).

Scandinavian, US and Italian studies all reveal significant gender differences in attitudes towards pornography, with women being significantly more likely than men to describe pornography as dull, not exciting or repulsive and favour restrictions on pornography (e.g. Flood 2010; Herrman and Bordner 1983; Sabina, Wolak, and Finkelhor 2008; Træen, Spitznogle, and Beverfjord 2004). In an Indonesian context, Puspa (2010), using a sample of 98 Indonesian college students, found that attitudes toward pornography and common sexual behaviour (i.e., holding hands, hugging, kissing, petting and coitus) were positively correlated.

Up until the 1990s, the dominant media outlets for pornography consumption were magazines, videos/DVDs and television. However, this changed in the wake of the Internet and Smartphone revolution, where high-speed Internet connections increasingly allow for easy, cheap and convenient access to all types of pornography (Edelman 2009). Today, the predominant media outlets of pornography consumption are the Internet, videos/DVDs, television and magazines (Morgan 2011).

Few studies have examined the situational and interpersonal characteristics of pornographic consumption. In the studies done, however, for both men and women the main place of use has been found to be 'home' and the interpersonal context of use being either 'alone' or with a 'regular sexual partner' (e.g. Hald 2006; Svedin, Akerman, and Priebe 2011; Træen, Nilsen, and Stigum 2006).

Perceived realism of pornography, that is, the extent to which the consumer perceives the pornographic content as realistic (see also Peter and Valkenburg 2010; Stulhofer, Busko, and Schmidt 2012), has rarely been investigated in pornography research. However, in the studies conducted, perceived realism has been found to be significantly positively correlated with pornography consumption (Hald 2007), a mediator of the impact of internet pornography consumption on young people's instrumental attitudes toward sex (Peter and Valkenburg 2010) and a predictor of relationship intimacy (Stulhofer, Busko, and Schmidt 2012). Therefore, we think it of interest to also assess perceived realism of pornography in this sample.

\section{Pornography consumption and sexual behaviours}

Previous research in a range of cultural contexts has consistently found associations between pornography consumption and a variety of sexual behaviours. These include having pre-coital sexual behaviours, lower age at first intercourse, number of sexual partners, extramarital sex, having engaged in oral, anal or group sex, engaging in a larger range of sexual practices, not having used contraception during the last intercourse and having had a sexually transmitted infection (Braun-Courville and Rojas 2009; Brown and L'Engle 2009; Morgan 2011; Stulhofer, Busko, and Landripet 2010; Træen, Nilsen, and Stigum 2006; Wingood et al. 2001). In an Indonesian context, Novita, Hasanat, and 
Supriyati (2006) found that increased exposure to pornography was significantly associated with increases in young people's sexual behaviours. Reflecting the findings of this research, concerns have been raised that pornography may exert a potentially strong and adverse influence on sexual behaviours and increase sexual vulnerability and risk (Hald et al. 2013).

However, as Wright's (2012) review of the literature demonstrates, much of this previous research has failed to adequately assess and control for the combined influence of relevant controls and/or focus almost exclusively on STI-related sexual behavioural outcomes, e.g. condom use (e.g. Luder et al. 2011; Peter and Valkenburg 2011; Sinkovic, Stulhofer, and Bozic 2012; Wright 2012, 2013; Wright and Randall 2012). Both separately and combined, these limitations may result in overestimating or overstating the influence of pornography on sexual behaviours (Hald et al. 2013). Thus, to address these limitations of previous cross-sectional research, a more robust assessment of the associations between pornography and a broader range of sexual behaviours, controlling for other relevant covariates, is needed.

\section{Theoretical framework}

Theoretically, Sexual Script Theory has only recently emerged as a theoretical perspective to guide research and analyses of quantitative data pertaining to pornography. According to Frith and Kitzinger (2001), sexual scripts may be understood as "culturally available messages that define what "counts" as sex, how to recognise sexual situations, and what to do in sexual encounters' (210). Repeated exposure to pornography may influence the scripting process, the sexual scripts or the evaluation of sexual relations (Hald, Malamuth and Lange, forthcoming). Consequently, the explicit imagery, underlying messages, symbolic normative nature and order of sexual behaviors as portrayed in pornography may influence the affective, cognitive and behavioral aspects of sexuality (Stulhofer, Busko, and Landripet 2010) and the perceptions of sexuality (e.g. what is sex), sexual situations (e.g. when is a situation sexual), sexual behaviours (e.g. what to do when having sex) and evaluations of sexual relations (e.g. what constitutes good sex).

On this basis, Wright and colleagues have proposed the 3AM model, a sexual-scriptbased theory specifically developed to explain effects of media sex such as pornography (e.g. Wright 2013; Wright and Randall 2012). According to this model, pornography, through culturally available messages and social learning processes, may be written into the sexual scripts. However, the acquisition, activation and application of these sexual scripts is subject to a number of content, audience, and situational factors and do not happen automatically or uniformly across individuals (see also Wright 2013; Wright and Randall 2012). Based on previous research on pornography and sexual behaviours as well as on the 3AM model, we hypothesise that pornography consumption will be significantly associated with common sexual behaviours in non-marital relationships (specified below) over and above included control variables (also specified below).

By common sexual behaviours we refer to kissing, petting, oral sex and coitus (de Graaf et al. 2009; Herbenick et al. 2010; Smiler, Frankel, and Savin-Williams 2011). By non-marital relationships we refer to all relationships, whether casual or committed, in which consenting parties are not married. We focused on non-marital relationships as sex in Indonesia is normatively located within the institution of marriage (Nilan 2008). Consequently, asking participants about their attitudes toward marital sex or sexual behaviours within marital relations would most likely yield little response variation in 
relation to the common sexual behaviours studied. Further, most pornography portrays sexual relationships outside the marital context (Wright 2012).

By relevant control variables, we refer to variables previously shown or hypothesised to affect associations between pornography consumption and sexual behaviours. In our study these include socio-demographic characteristics (i.e., age, relationship status and religiosity) (Morgan 2011; Peter and Valkenburg 2011; Wright 2012; Wright and Randall 2012), personality characteristics (i.e., sensation seeking) (Luder et al. 2011; Peter and Valkenburg 2011), sexual background variables (i.e., sexual attitudes) (Luder et al. 2011), media use characteristics (i.e., Internet consumption per week) (Morgan 2011; Træen, Nilsen, and Stigum 2006) and parental involvement (Lam and Chan 2007; Sinkovic, Stulhofer, and Bozic 2012).

\section{Study aims and hypothesis}

The study aimed to investigate prevalence rates and patterns of pornography consumption using a large university sample of Indonesian young adults and a cross sectional design. Further, using this sample and design, the association between pornography consumption and sexual behaviours is investigated. In this regard, it is hypothesised that pornography consumption will be significantly associated with sexual behaviours over and above included controlling variables.

\section{Method \\ Participants}

Participants included 556 Indonesian college students aged 18-23 years from a wellknown private university in Surabaya, the second-largest city of Indonesia. Students at the university are ethnically and religiously diverse but predominantly middle class. Most students come from the greater Surabaya area (East Java) or other cities/islands in the central and eastern part of Indonesia, such as Kalimantan, Sulawesi, Maluku, Bali and Nusa Tenggara. The mean age of male subjects was 20.28 years $(S D=1.27)$. The mean age of female subjects was 19.96 ( $\mathrm{SD}=1.29 ; p=0.02$; independent $t$-test). For sociodemographic sample characteristics, see Table 1.

\section{Procedures}

The study protocol was approved by the Dean of the Faculty of Psychology and the Head of the Research and Community Service Board, University of Surabaya, Indonesia. Data were collected during June 2011. Four research assistants, three females and one male, randomly approached potential participants on the campus area of the university. A total of 578 potential participants were approached, of which 556 consented to participate in the study (96.2\%). After a short oral and written explanation of the study, consenting participants were asked to complete a formal form of consent followed by the study questionnaires. To guarantee participants' anonymity, consent forms were initially separated from the anonymous study questionnaires, which, upon completion, were dropped in a separate closed box. Due to the potentially sensitive nature of the topic, research assistants made sure that participants were alone during the questionnaire response phase. Further, participants were carefully instructed to leave items blank rather than giving dishonest answers to items they felt uncomfortable answering. 
Table 1. Background measures stratified by gender $(N=556)$.

\begin{tabular}{|c|c|c|c|c|c|}
\hline Variable & Men $\%$ & Women $\%$ & Tests & $d f$ & Cohen's $d$ \\
\hline Gender & $26.6(148)$ & $73.4(408)$ & & & \\
\hline Age & & & $\chi^{2}=8.49 *$ & 2 & 0.26 \\
\hline $18-19$ & $30.0(42)$ & $44.1(171)$ & & & \\
\hline $20-21$ & $55.0(77)$ & $44.3(172)$ & & & \\
\hline $22-23$ & $15.0(21)$ & $11.6(45)$ & & & \\
\hline Relationship status & & & $\chi^{2}=2.36$ & 1 & 0.13 \\
\hline Not in a relationship & $60.0(87)$ & $52.6(213)$ & & & \\
\hline In a relationship & $40.0(58)$ & $47.4(192)$ & & & \\
\hline $\begin{array}{l}\text { Average hours of religious } \\
\text { attendance per week }\end{array}$ & & & $t=-0.54$ & 517 & -0.05 \\
\hline$M$ & 6.3 & 7.2 & & & \\
\hline$S D$ & 15.7 & 16.7 & & & \\
\hline$N$ & 137 & 382 & & & \\
\hline Sensation seeking & & & $\chi^{2}=7.54$ & 3 & 0.23 \\
\hline Very high & $17.6(26)$ & $12.3(50)$ & & & \\
\hline High & $52.0(77)$ & $47.1(192)$ & & & \\
\hline Low & $25.7(38)$ & $37.3(152)$ & & & \\
\hline Very low & $4.7(7)$ & $3.4(14)$ & & & \\
\hline $\begin{array}{l}\text { Average hours of internet } \\
\text { use per week }\end{array}$ & & & $\chi^{2}=13.36 *$ & 4 & 0.32 \\
\hline $0-10$ & $57.3(82)$ & $66.5(264)$ & & & \\
\hline $11-20$ & $14.7(21)$ & $14.9(59)$ & & & \\
\hline $21-30$ & $12.6(18)$ & $12.6(50)$ & & & \\
\hline $31-40$ & $4.9(7)$ & $2.8(11)$ & & & \\
\hline More than 40 & $10.5(15)$ & $3.3(13)$ & & & \\
\hline Parental involvement & & & $\chi^{2}=4.45$ & 3 & 0.18 \\
\hline Very high & $25.3(37)$ & 33.8 (137) & & & \\
\hline High & $58.9(86)$ & $54.3(220)$ & & & \\
\hline Low & $15.1(22)$ & $11.6(47)$ & & & \\
\hline Very low & $0.7(1)$ & $0.2(1)$ & & & \\
\hline Sexual attitude ${ }^{a}$ & & & $t=3.34 * *$ & 552 & 0.28 \\
\hline$M$ & 10.8 & 9.8 & & & \\
\hline$S D$ & 3.3 & 3 & & & \\
\hline$N$ & 146 & 408 & & & \\
\hline Sexual behaviour ${ }^{\mathrm{b}}$ & & & $t=0.80$ & 548 & 0.11 \\
\hline$M$ & 1.4 & 1.3 & & & \\
\hline$S D$ & 1.7 & 1.3 & & & \\
\hline$N$ & 147 & 402 & & & \\
\hline
\end{tabular}

Note: Missing values excluded; numbers in parentheses represent $\mathrm{n} /$ cell; $* p<0.05 ; * * p<0.01$.

${ }^{a}$ Sexual attitude scores ranged from 5 to 20, with 5 indicating a strong negative attitude towards non-marital sexual behaviours and 20 indicating a strong positive attitude towards common non-marital sexual behaviours.

${ }^{\mathrm{b}}$ Sexual behaviour scores ranged from 0 to 5 , with higher scores indicating having engaged in a larger range of non-marital sexual activities.

\section{Measures}

\section{Main outcome measures}

Pornography consumption. Pornography related variables were measured using a modified version of the Pornography Consumption Questionnaire developed by Hald (2006). Items were related to prevalence rates of pornography consumption, the situational and interpersonal context of pornography consumption, pornography consumption outlets, acceptance of pornography consumption (i.e., the extent to which the viewing of pornography is acceptable for adults above 18 years of age), perceived realism of 
pornography (i.e., the extent to which the consumer perceives the pornographic content as realistic) and partner knowledge of and reactions to participant's pornography consumption (Carroll et al. 2008; Hald 2006; Hald and Malamuth 2008; Stulhofer, Busko, and Schmidt 2012). Following Hald (2006), participants were told to refer to the following definition of pornography whenever the term was used throughout the questionnaire:

Any kind of material aiming at creating or enhancing sexual feelings or thoughts in the recipient and, at the same time, containing explicit exposure and/or descriptions of the genitals and clear and explicit sexual acts such as vaginal intercourse, anal intercourse, oral sex, masturbation, bondage, sadomasochism, rape, urine sex, animal sex, etc. (579)

To yield a better overall estimate of pornography consumption, following Hald (2006) and Hald and Malamuth (2008), several indicators of pornography consumption (time since last consumption, frequency of consumption, duration of consumption) were collapsed into a 'pornography consumption composite' measure, using the average standardised score of the indicators. The pornography consumption composite was used in all subsequent analyses.

Non-marital sexual behaviours. Non-marital sexual behaviours (sexual behaviours) were measured using five sexual behavioural items indicating whether participants had engaged in certain sexual activities in non-marital relationships. These included dry kissing (mouth-to-mouth kiss without involving saliva), deep kissing (mouth-to-mouth kiss involving saliva), petting (manual stimulation of erogenous zones), oral sex (oral-genital stimulation) and coitus (penetration with the penis) (Herbenick et al. 2010). Responses were given in a 'yes' and 'no' manner $(0=$ no/never engaged in the activity, $1=$ yes/have engaged in the activity). A 'sexual behaviour score' was computed by summing scores across items. Higher scores indicate having engaged in more sexual behaviours outside marital relationships.

\section{Controlling variables (covariates)}

Socio-demographic variables. Sociodemographic variables included gender, age (in years $)$, relationship status $(0=$ not in a relationship; $1=$ in a relationship $)$ and religious attendance. Religious attendance was assessed as the average time per week in hours spent on religious activities, whether individually or communally (see also Rohrbaugh and Jessor 1975).

Internet consumption. Internet consumption was measured by the average number of hours of internet use per week during the previous 12 months.

Parental involvement. Parental involvement was measured by six items taken from Lam and Chan (2007). Parental involvement refers to the degree of 'participation of parents/guardians in the children's life and their dedication in trying to help solve their children's problems' (Lam and Chan 2007, 592). Responses ranged from $1=$ strongly disagree to $4=$ strongly agree. Higher scores indicate more parental involvement in the participants' life. The internal consistency of the scale was satisfactory (Cronbach's $\alpha=0.76$ ).

Sensation seeking. Sensation seeking was assessed using the eight-item Brief Sensation Seeking Scale developed by Stephenson et al. (2007). Responses ranged from 1 (strongly disagree) to 4 (strongly agree). Higher scores indicate higher sensation seeking. Internal consistency of the scale was satisfactory (Cronbach's $\alpha=0.74$ ). 
Attitude towards non-marital sexual behaviours. Attitude towards non-marital sexual behaviours (sexual attitude) was assessed using five items measuring participants' attitude towards certain sexual activities in non-marital relationships. Items included dry kissing (mouth-to-mouth kisses without involving saliva), deep kissing (mouth-to-mouth kiss involving saliva), petting (manual stimulation of erogenous zones), oral sex (oral-genital stimulation) and coitus (sex involving penetration with the penis) (Herbenick et al. 2010). These items were chosen to align with the study outcome measure of 'non-marital sexual behaviours' described below. Responses were given on a four-point scale $(1=$ highly unacceptable; $2=$ unacceptable; $3=$ acceptable; $4=$ highly acceptable). A sexual attitude composite score was created by summing scores on each item. Higher scores indicate a more positive attitude towards sexual activities in non-marital relationships. The internal consistency of the scale was good (Cronbach's $\alpha=0.85$ ).

\section{Results}

\section{Missing data}

Gender stratified missing value analyses were performed for all included variables due to the sensitive nature of the topic. Except for variables related to 'partner's knowledge of participant's pornography consumption' and 'type of sexual activity accompanying pornography consumption', missing values ranged from 0 to $8 \%$, with the vast majority of missing values being below 5\%. For the two items noted above, missing values ranged from 7 to $18 \%$. No systematic differences between respondents and non-respondents were found across missing values (see also Howell 2007).

\section{Background variables}

No significant gender differences were evident for relationship status, sensation seeking, parental involvement, religious attendance or sexual behaviours. However, compared to women, men were found to be significantly older, spend significantly more time on Internet use per week and hold significantly more positive sexual attitudes $(p<0.05)$. The magnitude of these differences was found to be small to moderate (Cohen's $d$ range: $0.26-$ 0.32, see also Table 1).

\section{Patterns of pornography consumption}

With two exceptions, noted below, significant gender differences were found across all measures of pornography consumption (see Table 2). The magnitude of these differences were predominantly found to be large (Cohen's $d>0.8$ ).

Significantly more men than women were found to have ever consumed pornography $(p<0.01)$. Men were also found to have been exposed to pornography at a significantly younger age than women, spend significantly more time on pornography consumption, consume pornography significantly more often and have consumed pornography significantly more recently than women $(p<0.01)$. Further, men's consumption of pornography was significantly more often accompanied by solitary sexual activity than women's $(p<0.05)$. Significantly more women $(34.9 \%)$ than men $(7.8 \%)$ reported to have had sexual activity with a partner during pornography consumption $(p<0.01)$. For both genders, pornography was most often accessed from home, through the Internet, a Mobile phone or a DVD/VCD and used in solitude. No significant gender differences were found in the acceptance of pornography, with the majority of both men and women 
Table 2. Pornography consumption measures stratified by gender $(N=556)$.

\begin{tabular}{|c|c|c|c|c|c|}
\hline Variable & Men $\%$ & Women $\%$ & Tests & $d f$ & Cohen's $d$ \\
\hline Pornography consumption & & & $\chi^{2}=27.47 * *$ & 1 & 0.46 \\
\hline Yes & $94.6(140)$ & $74.4(302)$ & & & \\
\hline No & $5.4(8)$ & $25.6(104)$ & & & \\
\hline Age of first exposure & & & $t=-6.64 * *$ & 437 & 0.64 \\
\hline$M$ & 14.4 & 16.1 & & & \\
\hline$S D$ & 2.4 & 2.7 & & & \\
\hline$N$ & 138 & 301 & & & \\
\hline Time since last consumption & & & $\chi^{2}=151.70 * *$ & 6 & 1.45 \\
\hline In the last 24 hours & $7.1(10)$ & $1.7(5)$ & & & \\
\hline In the last 48 hours & $7.1(10)$ & $1.0(3)$ & & & \\
\hline In the last week & $35.0(49)$ & $4.0(12)$ & & & \\
\hline In the last month & $24.3(34)$ & $10.6(32)$ & & & \\
\hline In the last 6 months & $10.7(15)$ & $16.6(50)$ & & & \\
\hline In the last year & $7.9(11)$ & $18.3(55)$ & & & \\
\hline More than 1 year ago & $7.9(11)$ & $47.8(144)$ & & & \\
\hline $\begin{array}{l}\text { Frequency of pornography consumption } \\
\text { in the last six months }\end{array}$ & & & $\chi^{2}=160.10 * *$ & 5 & 1.52 \\
\hline Never & $15.9(22)$ & $66.6(199)$ & & & \\
\hline More than five times per week & $5.8(8)$ & $0.3(1)$ & & & \\
\hline $3-5$ times per week & $8.0(11)$ & $0.7(2)$ & & & \\
\hline $1-2$ times per week & $29.0(40)$ & $2.3(7)$ & & & \\
\hline $1-2$ times per month & $21.7(30)$ & $6.7(20)$ & & & \\
\hline Less than once per month & $19.6(27)$ & $23.4(70)$ & & & \\
\hline $\begin{array}{l}\text { Duration of use (hours per week } \\
\text { in the last } 6 \text { months) }\end{array}$ & & & $\chi^{2}=115.20 * *$ & 5 & 1.25 \\
\hline Never & $16.9(22)$ & $71.6(199)$ & & & \\
\hline Less than 1 hour & $26.9(35)$ & $14.0(39)$ & & & \\
\hline $1-3$ hours & $50.0(65)$ & $13.7(38)$ & & & \\
\hline $4-6$ hours & $3.8(5)$ & $0.4(1)$ & & & \\
\hline $7-10$ hours & $0.8(1)$ & $0.4(1)$ & & & \\
\hline More than 10 hours & $1.5(2)$ & $0(0)$ & & & \\
\hline Location of pornography consumption & & & $\chi^{2}=20.00 * *$ & 3 & 0.45 \\
\hline Home & $77.0(107)$ & $55.1(152)$ & & & \\
\hline Friend's home & $7.9(11)$ & $20.3(56)$ & & & \\
\hline Internet café & $2.2(3)$ & $2.5(7)$ & & & \\
\hline Campus & $0.7(1)$ & $7.6(21)$ & & & \\
\hline $\begin{array}{l}\text { Other (not specified, anywhere, } \\
\text { workplace, WiFi area, etc.) }\end{array}$ & $12.2(17)$ & $14.5(40)$ & & & \\
\hline \multicolumn{6}{|l|}{$\begin{array}{l}\text { Interpersonal context of pornography } \\
\text { consumption }^{\mathrm{a}}\end{array}$} \\
\hline Alone & $89.8(106)$ & $58.8(60)$ & $\chi^{2}=128.40 * *$ & 1 & 1.28 \\
\hline Romantic partner & $0.8(1)$ & $14.7(15)$ & $\chi^{2}=4.93 *$ & 1 & 0.21 \\
\hline A friend & $2.5(3)$ & $11.8(12)$ & $\chi^{2}=0.97$ & 1 & 0.09 \\
\hline A group of friends & $15.3(18)$ & $43.1(44)$ & $\chi^{2}=0.22$ & 1 & 0.04 \\
\hline Other & $1.7(2)$ & $2.9(3)$ & $\chi^{2}=0.17$ & 1 & 0.04 \\
\hline $\begin{array}{l}\text { Most frequent type of pornography } \\
\text { consumption outlet }\end{array}$ & & & $\chi^{2}=31.16 * *$ & 4 & 0.56 \\
\hline Internet & $63.6(89)$ & $39.6(112)$ & & & \\
\hline DVD/VCD & $17.9(25)$ & $24.4(69)$ & & & \\
\hline Cell phone & $9.3(13)$ & $25.8(73)$ & & & \\
\hline Printed magazine & $0.7(1)$ & $4.6(13)$ & & & \\
\hline
\end{tabular}


Table 2 - continued

\begin{tabular}{|c|c|c|c|c|c|}
\hline Variable & Men $\%$ & Women $\%$ & Tests & $d f$ & Cohen's $d$ \\
\hline Other & $8.6(12)$ & $5.7(16)$ & & & \\
\hline $\begin{array}{l}\text { Does sexual activity accompanies } \\
\text { pornography consumption? }\end{array}$ & & & $\chi^{2}=145.90 * *$ & 3 & 1.43 \\
\hline Always & $2.9(4)$ & $1.0(3)$ & & & \\
\hline Often & $16.4(23)$ & $1.4(4)$ & & & \\
\hline Sometimes & $53.6(75)$ & $12.4(36)$ & & & \\
\hline Never & $27.1(38)$ & $85.2(247)$ & & & \\
\hline \multicolumn{6}{|l|}{$\begin{array}{l}\text { Context in which sexual activity } \\
\text { accompany pornography consumption }{ }^{\mathrm{a}}\end{array}$} \\
\hline Solitaire & $89.2(91)$ & $67.4(29)$ & $\chi^{2}=4.91 *$ & 1 & 0.38 \\
\hline With partner & $7.8(8)$ & $34.9(15)$ & $\chi^{2}=19.38 * *$ & 1 & 0.80 \\
\hline $\begin{array}{l}\text { Acceptance of pornography consumption } \\
\text { for adults }>18 \text { years of age }\end{array}$ & & & $\chi^{2}=7.09$ & 3 & 0.23 \\
\hline Highly acceptable & $15.0(22)$ & $7.9(32)$ & & & \\
\hline Acceptable & $59.9(88)$ & $69.2(279)$ & & & \\
\hline Unacceptable & $17.7(26)$ & $16.1(65)$ & & & \\
\hline Highly unacceptable & $7.5(11)$ & $6.7(27)$ & & & \\
\hline Perceived realism of pornography ${ }^{b}$ & & & $t=-0.72$ & 427 & -0.07 \\
\hline$M$ & 4.4 & 4.6 & & & \\
\hline$S D$ & 2.1 & 2.1 & & & \\
\hline$N$ & 140 & 289 & & & \\
\hline $\begin{array}{l}\text { Partner knowledge of participant's } \\
\text { pornography consumption }\end{array}$ & & & $\chi^{2}=19.46 * *$ & 1 & 0.47 \\
\hline Yes & $37.1(43)$ & $61.8(155)$ & & & \\
\hline No & $62.9(73)$ & $38.2(96)$ & & & \\
\hline Partner's response if knowing & & & $\chi^{2}=23.33 * *$ & 2 & 0.67 \\
\hline Supporting & $1.5(1)$ & $4.8(8)$ & & & \\
\hline Neither supporting nor opposing & $37.9(25)$ & $68.3(114)$ & & & \\
\hline Opposing & $60.6(40)$ & $26.9(45)$ & & & \\
\hline
\end{tabular}

Note: Missing values excluded; numbers in parentheses represent $\mathrm{n} /$ cell; $* p<0.05 ; * * p<0.01$.

${ }^{a}$ For interpersonal context of use and type of activity accompanying pornography consumption participants were allowed to select more than one option;

${ }^{\mathrm{b}}$ Responses ranged from $1=$ very unrealistic to $9=$ very realistic.

reporting acceptance of pornography consumption. Finally, no significant gender differences were found for the perception of pornography as realistic.

\section{The association between pornography consumption and sexual behaviours}

To test our study hypothesis that pornography consumption would be significantly associated with common sexual behaviours in non-marital relationships over and above relevant control variables, we employed a two-step analytic approach in our hierarchical multiple regression analyses. In the first step, socio-demographic, personality, sexual background, media use and parental involvement control variables (i.e., age, relationship status, and religiosity, sensation seeking, sexual attitudes, Internet consumption per week and parental involvement) were force entered into the regression analyses. In the second step, the pornography consumption composite was force entered into the regression analyses.

Across gender, the final model for sexual behaviours was significant (Men: $F[8,99]=$ 4.64, $p<0.000, R_{\text {adj }}^{2}=0.21$; Women: $\left.F[8,246]=28.49, p<0.000, R_{\text {adj }}^{2}=0.46\right)$. However, as evident from Table 3 , for men only, pornography consumption significantly 
Table 3. Hierarchical regression analyses predicting sexual behaviour.

\begin{tabular}{|c|c|c|c|}
\hline & $\Delta R^{2}$ & B & $T$ \\
\hline \multicolumn{4}{|l|}{$\operatorname{Men}(n=140)$} \\
\hline Step 1 & $0.17 * *$ & & \\
\hline Age & & -0.11 & -1.21 \\
\hline Relationship status & & 0.20 & $2.17 *$ \\
\hline Religious attendance & & -0.10 & -0.89 \\
\hline Sensation seeking & & 0.12 & 1.37 \\
\hline Sexual attitude & & 0.30 & $3.07 * *$ \\
\hline Internet use & & 0.10 & 0.91 \\
\hline Parental involvement & & 0.01 & 0.13 \\
\hline Step 2 & $0.05 *$ & & \\
\hline Pornography consumption & & 0.23 & $2.48 *$ \\
\hline $\begin{array}{l}\text { Total } \Delta R^{2} \text { adjusted } \\
\text { Women }(n=302)\end{array}$ & $0.21 * *$ & & \\
\hline Step 1 & $0.46 * *$ & & \\
\hline Age & & 0.03 & 0.62 \\
\hline Relationship status & & 0.19 & $3.98 * *$ \\
\hline Religious attendance & & 0.05 & 0.90 \\
\hline Sensation seeking & & 0.22 & $4.45 * *$ \\
\hline Sexual attitude & & 0.51 & $9.97 * *$ \\
\hline Internet use & & -0.02 & -0.30 \\
\hline Parental involvement & & 0.01 & 0.11 \\
\hline Step 2 & 0.01 & & \\
\hline Pornography consumption & & 0.09 & 1.87 \\
\hline Total $\Delta R^{2}$ adjusted & $0.46 * *$ & & \\
\hline
\end{tabular}

Note: Missing values deleted 'listwise'; $* p<0.05 ; * * p<0.01$.

added to the total explained variance of sexual behaviours over and above included control variables accounting for an additional $5 \%$ of this variance $\left(R_{\text {change }}^{2}=0.05\right)$.

\section{Discussion}

Using a sample of university students from a religious, sexually conservative, Muslimmajority country with strict anti-pornography laws, the study found that among this Indonesian sample, pornography is as widely and readily consumed and accepted as in comparable international studies predominantly using Western-background samples from more sexually liberal and less religious countries with no or very few laws on pornography (Hald 2006; Morgan 2011; Peter and Valkenburg 2011). Furthermore, gender differences in pornography consumption patterns and rates in this Indonesian sample were pronounced and comparable with that of their international counterparts, with men consuming pornography significantly more often, with higher duration, at an earlier age and more often during solitary sexual activity than women.

These findings help to validate findings from recent Indonesian studies on young people's sexuality demonstrating a constant liberalisation of Indonesian youth sexuality during the past decade (Harding 2008; Utomo 1997; Utomo and McDonald 2008). Also, it gives an indication that the effectiveness of the Indonesian anti-pornography law may be less than intended, although the unavailability of baseline data and choice of study design preclude such definitive conclusions. However, if correct, this ineffectiveness may be due to the pluralism inherent to Indonesian culture (Blackwood 2007; Boellstorff 2007; Wright-Webster 2008), in which political laws and policies concerning sexuality are 
continuously challenged and contested (see also Introduction) and often weakly enforced by authorities (Assegaf 2002).

Interestingly, and in contrast to previous findings (e.g. Træen, Spitznogle, and Beverfjord 2004), no gender differences in acceptance of pornography were found, with the vast majority of both genders finding pornography acceptable. This may be because, across gender, both attitudinally and behaviourally sexual permissiveness is on the rise in Indonesia, as demonstrated in recent research utilising Indonesian samples (see also Bennett 2007; Simon and Paxton 2004). Also, it may be due to peer interactions and/or youth sexual lifestyles in which the normative discourse, across gender, is that of positive attitudes towards pornography and pornography consumption (see also Ford, Shaluhiyah, and Suryoputro 2007).

Partly supporting our study hypothesis, for men, pornography consumption was found to be significantly associated with common sexual behaviours in non-marital relations over and above control variables accounting for an additional 5\% of the total explained variance in these behaviours. This finding corresponds to previous findings in the area predominantly using STI-related sexual-risk behavioural outcomes (Luder et al. 2011; Peter and Valkenburg 2011; Sinkovic, Stulhofer, and Bozic 2012). Among women, the lack of significant association was contrary to our study hypothesis and highlights the possibility that pornography consumption may in fact not be significantly associated with sexual behaviours. Alternatively, that, among women, these associations are accounted for by other factors included in this study as controls (Luder et al. 2011).

Theoretically, among men, the finding that pornography consumption only modestly contributes to non-marital sexual behaviours fits with the basic contention of sexual script theory and the 3AM model (see Introduction). That is, the continuous reshaping of sexual scripts and influence of pornography on sexual behaviours depends on a multitude of culturally mediated messages about sex and sexual relations, such as sexual experiences, motivations, emotional investments and so on, and not only on pornography per se (see also Wright, Malamuth, and Donnerstein 2012).

The current study has several limitations. First, due to the recruitment and sampling procedures, the study probably includes a non-probability type sample and therefore the study findings cannot be generalised to the Indonesian population at large. Second, the cross-sectional design of the study precludes the assessment of causality. Third, this is the first survey study of pornography consumption and associated variables ever published using a sample of this type. Therefore, we lack an adequate body of literature in which to situate our findings. Thus, more research is needed to inform such questions as the generalisability of the study results. Fourth, the study does not differentiate between different kinds of non-marital relationships. This is a limitation because pattern of pornography consumption and pornography consumption-sexual behavioural associations may vary across different types of non-marital relationships. Fifth, the study relies on selfreport, which may be subject to a variety of systematic biases (van de Mortel 2008).

Nevertheless this study advances research on pornography by providing the first insights into pornography consumption and associated factors in a religious, sexually conservative, Muslim-majority country with strict anti-pornography laws. We encourage future research to utilise different comparable samples to validate the current study findings and provide further insight into pornography consumption and associated factors in Muslim majority nations. 


\section{References}

Allen, P. 2007. "Challenging Diversity? Indonesia's Anti-pornography Bill." Asian Studies Review 31 (2): $101-115$.

Assegaf, I. 2002. "Legends of the Fall: An Institutional Analysis of Indonesian Law Enforcement Agencies Combating Corruption." In Corruption in Asia: Rethinking the Governance Paradigm, edited by Tim Lindsey, and Howard Dick, 127-146. Sydney: The Federation Press.

Bennett, L. R. 2005a. "Patterns of Resistance and Transgression in Eastern Indonesia: Single Women's Practices of Clandestine Courtship and Cohabitation." Culture, Health \& Sexuality 7 (2): $101-112$.

Bennett, L. R. 2005b. Women, Islam and Modernity: Single Women, Sexuality and Reproductive Health in Contemporary Indonesia. New York: Routledge Curzon.

Bennett, L. R. 2007. "Zina and the Enigma of Sex Education for Indonesian Muslim Youth." Sex Education 7 (4): 371-386.

Blackwood, E. 2007. "Regulation of Sexuality in Indonesian Discourse: Normative Gender, Criminal Law, and Shifting Strategies of Control." Culture, Health \& Sexuality 9 (3): 293-307.

Boellstorff, T. 2007. Coincidence of Desires: Anthropology, Queer Studies, Indonesia. Durham, NC: Duke University Press.

BPS-Statistics Indonesia. 2010. The Number and Distribution of Population. Accessed September 26, 2012. http://sp2010.bps.go.id/

Braun-Courville, D. K., and M. Rojas. 2009. "Exposure to Sexually Explicit WebSites and Adolescent Sexual Attitudes and Behaviors." Journal of Adolescent Health 45 (2): 156-162.

Brown, J. D., and K. L. L'Engle. 2009. "X-rated: Sexual Attitudes and Behaviors Associated with U.S. Early Adolescents' Exposure to Sexually Explicit Media." Communication Research 36 (1): $129-151$.

Carroll, J. S., L. M. Padilla-Walker, L. J. Nelson, C. D. Olson, C. M. Barry, and S. D. Madsen. 2008. "Generation XXX: Pornography Acceptance and Use among Emerging Adults." Journal of Adolescent Research 23 (1): 6-30.

Chivers, M., M. Seto, M. Lalumiere, E. Laan, and T. Grimbos. 2010. "Agreement of Self-reported and Genital Measures of Sexual Arousal in Men and Women: A Meta-analysis." Archives of Sexual Behavior 39 (1): 5-56.

Davies, S. G. 2010. Gender Diversity in Indonesia: Sexuality, Islam and Queer Selves. London: Routledge.

de Graaf, H., I. Vanwesenbeeck, S. Meijer, L. Woertman, and W. Meeus. 2009. "Sexual Trajectories During Adolescence: Relation to Demographic Characteristics and Sexual Risk." Archives of Sexual Behavior 38 (2): 276-282.

Diarsvitri, W., I. D. Utomo, T. Neeman, and A. Oktavian. 2011. "Beyond Sexual Desire and Curiosity: Sexuality among Senior High School Students in Papua and West Papua Provinces (Indonesia) and Implications for HIV Prevention." Culture, Health \& Sexuality 13 (9): $1047-1060$.

Edelman, B. 2009. “Markets: Red Light States: Who Buys Online Adult Entertainment?” Journal of Economic Perspectives 23 (1): 209-220.

Flood, M. 2010. "Young Men Using Pornography." In Everyday Pornography, edited by Karen Boyle, 164-178. New York: Routledge.

Ford, N. J., Z. Shaluhiyah, and A. Suryoputro. 2007. "A Rather Benign Sexual Culture: Socio-sexual Lifestyles of Youth in Urban Central Java, Indonesia." Population, Space and Place 13 (1): $59-76$.

Frith, H., and C. Kitzinger. 2001. "Reformulating Sexual Script Theory: Developing a Discursive Psychology of Sexual Negotiation." Theory and Psychology 11 (2): 209-232.

Hald, G. M. 2006. "Gender Differences in Pornography Consumption among Young Heterosexual Danish Adults." Archives of Sexual Behavior 35 (5): 577-585.

Hald, G. M. 2007. "Gender Differences in Behavioral, Situational, and Interpersonal Patterns of Pornography Consumption." In Generation P - Youth, Gender and Pornography, edited by S. Knudsen, L. Löfgren-Mårtenson, and S. A. Månsson, 118-133. Copenhagen: Danish School of Education Press.

Hald, G. M., L. Kuyper, P. C. G. Adam, and J. B. F. De Wit. 2013. "Does Viewing Explain Doing? Assessing the Association between Sexually Explicit Materials Use and Sexual Behaviours in a Large Sample of Dutch Adolescents and Young Adults." Journal of Sexual Medicine. Advance online publication. doi: $10.1111 /$ jsm.12157. 
Hald, G. M., and N. M. Malamuth. 2008. "Self-perceived Effects of Pornography Consumption." Archives of Sexual Behavior 37 (4): 614-625.

Hald, G. M. T. Lange, and N. M. Malamuth, Forthcoming. "Pornography and Sexist Attitudes among Heterosexuals". Journal of Communication.

Harding, C. 2008. "The Influence of the "Decadent West": Discourses of the Mass Media on Youth Sexuality in Indonesia [online version]." Intersections: Gender and Sexuality in Asia and the Pacific 18. http://intersections.anu.edu.au/issue18/harding.htm

Herbenick, D., M. Reece, V. Schick, S. A. Sanders, B. Dodge, and J. D. Fortenberry. 2010. "Sexual Behavior in the United States: Results From a National Probability Sample of Men and Women Ages 14-94.” The Journal of Sexual Medicine 7 (Suppl. 5): 255-265.

Herrman, M. S., and D. C. Bordner. 1983. "Attitudes toward Pornography in a Southern Community." Criminology 21 (3): 349-374.

Holzner, B. M., and D. Oetomo. 2004. "Youth, Sexuality and Sex Education Messages in Indonesia: Issues of Desire and Control." Reproductive Health Matters 12 (23): 40-49.

Houben, V. J. H. 2003. "Southeast Asia and Islam." The Annals of the American Academy of Political and Social Science 588 (1): 149-170.

Howell, D. C. 2007. "The Treatment of Missing Data." In The SAGE Handbook of Social Science Methodology, edited by William Outhwaite, and Stephen Turner, 208-224. London: Sage.

Jacubowski, N. 2008. "Marriage is Not a Safe Place: Heterosexual Marriage and HIV-related Vulnerability in Indonesia." Culture, Health \& Sexuality 10 (1): 87-97.

Jennaway, M. 2003. "Displacing Desire: Sex and Sickness in North Bali." Culture, Health \& Sexuality 5 (3): 185-201.

Kitley, P. 2008. "Playboy Indonesia and the Media: Commerce and the Islamic Public Sphere on Trial in Indonesia." South East Asia Research 16 (1): 85-116.

Lam, C. B., and D. K. S. Chan. 2007. "The Use of Cyberpornography by Young Men in Hong Kong: Some Psychosocial Correlates." Archives of Sexual Behavior 36 (4): 588-598.

Luder, M. T., I. Pittet, A. Berchtold, C. Akre, P. Michaud, and J. C. Suris. 2011. "Associations between Online Pornography and Sexual Behavior among Adolescents: Myth or Reality?" Archives of Sexual Behavior 40 (5): 1027-1035.

Ministry of Religious Affairs. 2005. Jumlah penduduk menurut agama [Population by Religion]. Accessed September 26, 2012. http://www.kemenag.go.id/file/dokumen/Data0801.pdf

Morgan, E. M. 2011. "Associations between Young Adults' Use of Sexually Explicit Materials and Their Sexual Preferences, Behaviors, and Satisfaction." Journal of Sex Research 48 (6): $520-530$.

Munro, J. 2012. “'A Diploma and a Descendant!' Premarital Sexuality, Education and Politics among Dani University Students in North Sulawesi, Indonesia." Journal of Youth Studies 15 (8): $1011-1027$.

Nilan, P. 2008. "Youth Transitions to Urban, Middle-class Marriage in Indonesia: Faith, Family and Finances." Journal of Youth Studies 11 (1): 65-82.

Nilsson, F. L. 2010. "Politics of Pornography: A Critical Human Rights Approach to the Pornography Legislation in Indonesia." Master's thesis, Lund Universitet, Sweden.

Novita, N., N. U. Hasanat, and D. Supriyati. 2006. "The Relationship between Pornography Exposure, Parental Sexual Communication, and Sexual Behavior in State High School 11 Palembang." [Hubungan antara paparan pornografi dan komunikasi seksual remaja-orang tua dengan perilaku seksual di SMA Negeri 11 Palembang] Sains Kesehatan 19: 127-136.

Padang, H. 2012. "Promiscuous Couple Raided by Neighbours." [Pasangan Mesum Digerebek Warga] Sindikasi Inilah. Accessed April 9. http://sindikasi.inilah.com/read/detail/1848909/pas angan-mesum-digerebek-warga

Peter, J., and P. M. Valkenburg. 2010. "Processes Underlying the Effects of Adolescents' Use of Sexually Explicit Internet Material: The Role of Perceived Realism." Communication Research 37 (3): 375-399.

Peter, J., and P. M. Valkenburg. 2011. "The Influence of Sexually Explicit Internet Material on Sexual Risk Behavior: A Comparison of Adolescents and Adults." Jounal of Health Communication: International Perspectives 16 (7): 750-765.

Puspa, S. V. 2010. The Relationship between Intensity of Love, Attitude toward Pornography, and Sexual Behavior among Emerging Adults [Hubungan antara intensitas cinta dan sikap terhadap pornografi dengan perilaku seksual pada dewasa awal yang berpacaran]. Unpublished thesis, Diponegoro University, Semarang, Indonesia. http://eprints.undip.ac.id/11115/1/intisari.pdf 
Rohrbaugh, J., and R. Jessor. 1975. "Religiosity in Youth: A Personal Control against Deviant Behavior." Journal of Personality 43 (1): 136-155.

Sabina, C., J. Wolak, and D. Finkelhor. 2008. "The Nature and Dynamics of Internet Pornography Exposure for Youth." Cyberpsychology and Behavior 11 (6): 691-693.

Sherlock, S. 2008. "Parties and Decision-making in the Indonesian Parliament: A Case Study of RUU APP, the Anti-pornography Bill.” Australian Journal of Asian Law 10 (2): 159-183.

Simon, S., and S. J. Paxton. 2004. "Sexual Risk Attitudes and Behaviours among Young Adult Indonesians." Culture, Health Sexuality 6 (5): 393-409.

Sinkovic, M., A. Stulhofer, and J. Bozic. 2012. "Revisiting the Association between Pornography Use and Risky Sexual Behaviors: The Role of Early Exposure to Pornography and Sexual Sensation Seeking." Journal of Sex Research. Advance online publication. doi: 10.1080/ 00224499.2012.681403

Situmorang, A. 2003. Adolescent Reproductive Health in Indonesia. Jakarta: USAID.

Smiler, A. P., L. B. W. Frankel, and R. C. Savin-Williams. 2011. "From Kissing to Coitus? Sex-ofPartner Differences in the Sexual Milestone Achievement of Young Men." Journal of Adolescence 34 (4): 727-735.

Stephenson, M. T., L. F. Velez, P. Chalela, A. Ramirez, and R. H. Hoyle. 2007. "The Reliability and Validity of the Brief Sensation Seeking Scale (BSSS-8) with Young Adult Latino Workers: Implications for Tobacco and Alcohol Disparity Research.” Addiction 102 (Suppl. 2): 79-91.

Stulhofer, A., V. Busko, and I. Landripet. 2010. "Pornography, Sexual Socialization, and Satisfaction among Young Men." Archives of Sexual Behavior 39 (1): 168-178.

Stulhofer, A., V. Busko, and G. Schmidt. 2012. "Adolescent Exposure to Pornography and Relationship Intimacy in Young Adulthood." Psychology and Sexuality 3 (2): 95-107.

Supriati, E., and S. Fikawati. 2009. "Efek paparan pornografi pada remaja SMP negeri kota Pontianak tahun 2008 [Effect of Pornography Exposure among Pontianak Junior High School Adolescents in 2008]." Makara Sosial Humaniora 13: 48-56.

Svedin, C. G., I. Akerman, and G. Priebe. 2011. "Frequent Users of Pornography. A Population Based Epidemiological Study of Swedish Male Adolescents." Journal of Adolescence 34 (4): 779-788.

The President of the Republic of Indonesia. 2008. Republic of Indonesia Law Number 44 year 2008 about Pornography [Undang-undang Republik Indonesia Nomor 44 Tahun 2008 tentang Pornografi]. Accessed September 26, 2012. http://www.bpkp.go.id/uu/filedownload/2/33/151. bpkp

The President of the Republic of Indonesia. 1974. Republic of Indonesia Law Number 1 year 1974 about Marriage [Undang-undang Republik Indonesia Nomor 1 Tahun 1974 tentang Perkawinan]. Accessed September 26, 2012. http://www.bkn.go.id/bapek/peraturan/ undang-undang-uu/82-uu-no-1-tahun-1974-tentang-perkawinan.html

Træen, B., T. S. Nilsen, and H. Stigum. 2006. "Use of Pornography in Traditional Media and on the Internet in Norway." Journal of Sex Research 43 (3): 245-254.

Træen, B., K. Spitznogle, and A. Beverfjord. 2004. "Attitudes and Use of Pornography in the Norwegian Population 2002." Journal of Sex Research 41 (2): 193-200.

Utomo, I. D. 1997. "Sexual Attitudes and Behaviour of Middle-class Young People in Jakarta." PhD Thesis, Australian National University, Canberra.

Utomo, I. D., and P. McDonald. 2008. "Religion, Media, Westernisation and Sexuality among Young People in Urban Middle-class Indonesia [online version]." Intersections: Gender and Sexuality in Asia and the Pacific 18. http://intersections.anu.edu.au/issue18/utomo_mcdonald. $\mathrm{htm}$

Utomo, I. D., and P. McDonald. 2009. "Adolescent Reproductive Health in Indonesia: Contested Values and Policy Inaction." Studies in Family Planning 40 (2): 133-146.

van de Mortel, T. F. 2008. "Faking It: Social Desirability Response Bias in Self-report Research." Australian Journal of Advanced Nursing 25 (4): 40-48.

Wieringa, S. E. 2000. "Communism and Women's Same-sex Practises in Post-Suharto Indonesia." Culture, Health \& Sexuality 2 (4): 441-457.

Wieringa, S. E. 2010. "Gender Variance in Asia: Discursive Contestations and Legal Implications." Gender, Technology \& Development 14 (2): 143-172.

Wingood, G. M., R. J. DiClemente, K. Harrington, S. Davies, E. W. Hook, and M. K. Oh. 2001. "Exposure to X-rated Movies and Adolescents' Sexual and Contraceptive-related Attitudes and Behaviors." Pediatrics 107 (5): 1116-1119. 
Withers, M., and C. H. Browner. 2012. "The Changing Contexts of Fertility Outcomes: Case Studies from a Remote Village in Bali, Indonesia." Culture, Health \& Sexuality 14 (3): 347-360.

Wright, P. J. 2012. "A Longitudinal Analysis of US Adults' Pornography Exposure: Sexual Socialization, Selective Exposure, and the Moderating Role of Unhappiness." Journal of Media Psychology: Theories, Methods, and Applications 24 (2): 67-76.

Wright, P. J. 2013. "U.S. Males and Pornography, 1973-2010: Consumption, Predictors, Correlates." Journal of Sex Research 50 (1): 60-71.

Wright, P., N. Malamuth, and E. Donnerstein. 2012. "Research on Sex in the Media: What do We Know about Effects on Children aTnd Adolescents." In Handbook of Chidren and the Media, edited by Dorothy G. Singer, and Jerome L. Singer, 273-302. Thousand Oaks, CA: Sage.

Wright, P. J., and A. K. Randall. 2012. "Internet Pornography Exposure and Risky Sexual Behavior among Adult Males in the United States." Computers in Human behavior 28 (4): 1410-1416.

Wright Webster, T. 2008. "(Re)articulations: Gender and Female Same-sex Subjectivities in Yogyakarta, Indonesia." Intersections: Gender and Sexuality in Asia and the Pacific 18. http:// intersections.anu.edu.au/issue18/wrightwebster.htm

\section{Résumé}

L'Indonésie est un pays religieux, conservateur vis-à-vis de la sexualité, avec une population majoritairement musulmane et des lois strictes contre la pornographie. Cette étude a examiné la prévalence et les modèles de la consommation de la pornographie en Indonésie parmi un échantillon d'étudiants universitaires indonésiens et en se basant sur une approche transversale. En outre, elle a exploré l'association entre la consommation de la pornographie et les comportements sexuels courants en dehors du mariage. L'étude a révélé que dans cet échantillon la pornographie était aussi largement et facilement consommée que dans des études internationales comparables qui avaient utilisé des échantillons de participants dont la majorité étaient des Occidentaux et vivaient dans des pays plus libéraux vis-à-vis de la sexualité et moins religieux, avec très peu de lois sur la pornographie. Dans les modèles de consommation de la pornographie, les différences de genre ont été significatives et comparables à celles qui avaient été révélées par les résultats d'autres études internationales semblables. Concernant uniquement les participants de sexe masculin, la consommation de pornographie s'est révélée en tant que facteur fortement prédictif des comportements sexuels courants en dehors du mariage. L'étude est la première à apporter un éclairage sur la prévalence et les modèles de la consommation de la pornographie, ainsi que sur l'association de cette dernière aux comportements sexuels courants en dehors du mariage, dans un pays conservateur vis-à-vis de la sexualité, avec une population à majorité musulmane et des lois strictes contre la pornographie.

\section{Resumen}

El presente estudio investigó las tasas de prevalencia y los patrones de consumo de pornografía en Indonesia, país religioso, sexualmente conservador, de mayoría musulmana y con severas leyes contra la pornografía, apoyándose en una muestra de estudiantes universitarios indonesios y en un diseño transversal. Asimismo, examinó la asociación entre el consumo de pornografía y los comportamientos sexuales extramaritales más comunes. El estudio constató que, en la muestra seleccionada, el consumo de pornografía era tan amplio y fácil como en países occidentales, más liberales desde el punto de vista sexual, menos religiosos y con pocas leyes que regulan la pornografía, según lo demuestran otros estudios internacionales realizados en este sentido. El consumo de pornografía dirigida sólo a hombres resultó predecir de manera significativa los comportamientos sexuales más comunes en las relaciones extramaritales. Este es el primer estudio que ofrece hallazgos en torno a las tasas de prevalencia y a los patrones de consumo de pornografía, así como en relación a su asociación con los comportamientos sexuales extramaritales comunes en un país sexualmente conservador, de mayoría musulmana, con estrictas leyes en contra de la pornografía. 


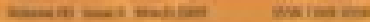

Poler Aesceion

waver

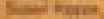

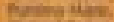

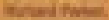

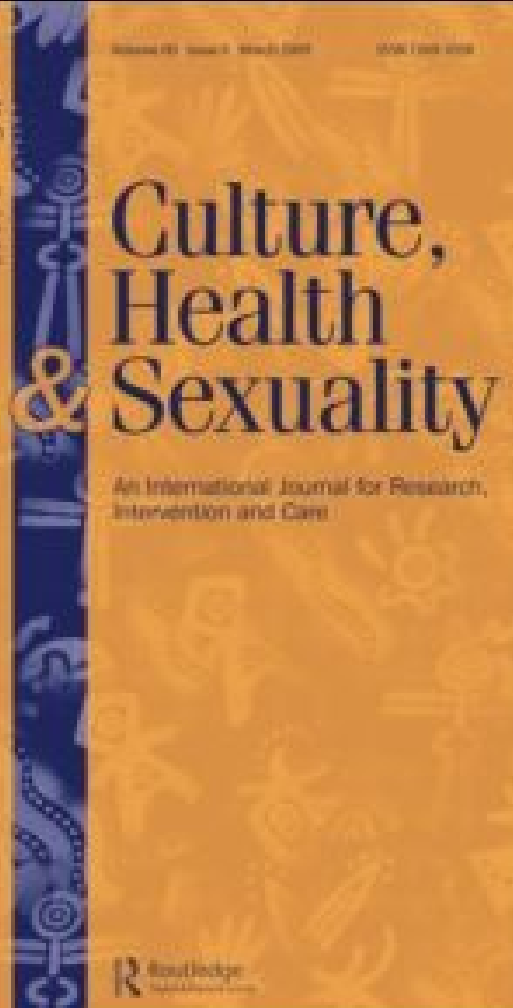


Journal

\title{
Culture, Health \& Sexuality >
}

\section{An International Journal for Research, Intervention and Care}

\author{
This journal
}

\section{Journal information}

Print ISSN: 1369-1058 Online ISSN: 1464-5351

12 issues per year

Culture, Health \& Sexuality is noted in: Anthropological Index; Anthropological Literature; CAB Health; CABI Information; Cambridge Scientific Abstracts; Caredata; CINAHL; CommunityWISE; Current Contents/Social \& Behavioral Sciences; EBSCO; Educational Research Abstracts online (ERA); EMBASE; European Reference Index for the Humanities and the Social Sciences (ERIH PLUS); Family Studies Database; FRANCIS; Gay \& Lesbian Abstracts (Sexual Diversity Studies); Health Economic Evaluations Database (OHE-HEED); Index Medicus/MEDLINE; International Bibliography of the Social Sciences; International Development Abstracts; ISI Alerting Services; Psychological Abstracts/ PsycINFO/ PsycLIT; the Prevention Evaluation Registry for Youth (PERRY); POPLINE; Scopus; Social Sciences Citation Index; Social Scisearch; Social Sciences Abstracts, Social Services Infonet and Social Services Abstracts, and Studies on Women and Gender Abstracts.

Taylor \& Francis make every effort to ensure the accuracy of all the information (the "Content") contained in our publications. However, Taylor \& Francis, our agents, and our licensors make no representations or warranties whatsoever as to the accuracy, completeness, or suitability for any purpose of the Content. Any opinions and views expressed in this publication are the opinions and views of the authors, and are not the views of or endorsed by Taylor \& Francis. The accuracy of the Content should not be relied upon and should be independently verified 
with primary sources of information. Taylor \& Francis shall not be liable for any losses, actions, claims, proceedings, demands, costs, expenses, damages, and other liabilities whatsoever or howsoever caused arising directly or indirectly in connection with, in relation to, or arising out of the use of the Content. Terms \& Conditions of access and use can be found at http://www.tandfonline.com/page/terms-and-conditions .

Sign in here

to start your access
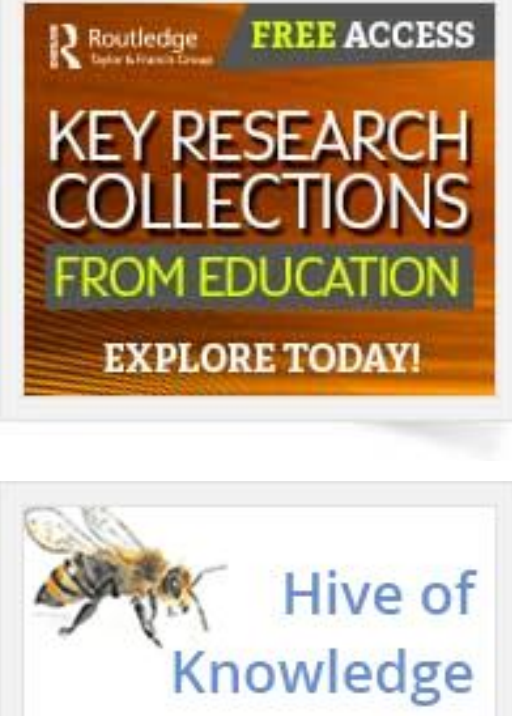

Cultivating a research community 


\section{Information for}

Authors

Editors

Librarians

Societies

Help and info

Help

FAQS

Press releases

Contact us

Commercial services
Open access

Overview

Open journals

Open Select

Cogent OA

Connect with Taylor \& Francis

f日e

You

Copyright $(2017$ Informa UK Limited Privacy policy \& cookies Terms \& conditions Accessibility

Registered in England \& Wales No. 3099067

5 Howick Place | London | SW1P 1WG 
Journal

\section{Culture, Health \& Sexuality >}

\section{An International Journal for Research, Intervention and Care}

\section{This journal}

\section{Editorial board}

\section{Editor:}

\section{Peter Aggleton}

Centre for Social Research in Health

UNSW Australia

Sydney, NSW 2052

Australia

\section{Founding Editors:}

Susan Kippax - UNSW Australia

Purnima Mane - Independent Consultant, USA

Richard Parker - Columbia University, USA

Barbara de Zalduondo - Independent Consultant, USA

\section{Editorial Advisory Board:}

Dan Allman - University of Toronto, Canada

Ana Amuchástegui - Universidad Autónoma Metropolitana-Xochimilco, Mexico

Stephen Bell - UNSW Australia

Shalini Bharat - Tata Institute of Social Sciences, Mumbai, India

Lisa Bowleg - The George Washington University, USA

Marian Burchardt - Max Planck Institute for the Study of Religious and Ethnic Diversity,

Germany 
Carlos Cáceres - Universidad Cayetano Heredia, Lima, Perú

Sonia Corrêa - ABIA, Rio de Janeiro, Brazil

Mary Crewe - University of Pretoria, South Africa

Gary Dowsett - La Trobe University, Australia

Gillian Fletcher - La Trobe University, Australia

Sarah Flicker - York University, Canada

Geeta Rao Gupta - Independent Consultant, USA

Abigail Harrison - Brown University School of Public Health, USA

Gilbert Herdt - San Francisco State University, USA

Hilary Homans - Independent Consultant, UK

Jaco Homsy - University of California San Francisco, USA

Roger Ingham - University of Southampton, UK

Carl Kendall - Tulane School of Public Health \& Tropical Medicine, USA

Le Minh Giang - Hanoi Medical University, Vietnam

Lígia Kerr Pontes - Universidade Federal de Ceará, Brazil

Ana Luisa Liguori - Ford Foundation, México

Pardis Mahdavi - Pomona College, USA

Lenore Manderson - University of the Witwatersrand, South Africa

Tsitsi Masvawure - College of the Holy Cross, Worcester, MA, USA

Rafael Mazín - Pan-American Health Organisation, Washington, USA

Anne-Lise Middelthon - University of Oslo, Norway

Elizabeth Mills - Institute of Development Studies, UK

Kåre Moen - University of Oslo, Norway

Marjorie Muecke - University of Pennsy/vania, USA

Charles Nzioka - University of Nairobi, Kenya

Don Operario - Brown University School of Public Health, USA

Lucia O'Sullivan - University of New Brunswick, Canada

Saroj Pachauri - Independent Consultant, New Delhi, India

Mark Padilla - School of Public Health, University of Michigan, Ann Arbor, USA

Vera Paiva - Universidade de São Paulo, Brazil

Suiming Pan - Renmin University of China, Beijing, China

Kane Race - University of Sydney, Australia

Theo Sandfort - Columbia University, New York, USA

K.G. Santhya - Population Council, New Delhi, India

Stephen L. Schensul - University of Connecticut, USA

Fiona Scorgie - University of the Witwatersrand, South Africa 
David Seal - Tulane University, USA

Janet Seeley - London School of Hygiene and Tropical Medicine, UK

Daniel Jordan Smith - Brown University, Providence, USA

Jonathan Stadler - University of the Witwatersrand, South Africa

Yvonne Szasz - El Colegio De México, México

Sylvia Tamale - Makerere University, Kampala, Uganda

Michael Tan - University of the Philippines, Philippines

Ravi Verma - International Center for Research on Women, New Delhi, India

Louise Vincent - Rhodes University, South Africa

Holly Wardlow - University of Toronto, Canada

Jeffrey Weeks - London South Bank University, UK

Mellissa Withers - University of Southern California, USA

Heather Worth - UNSW Australia

Sample Our

Humanities journals

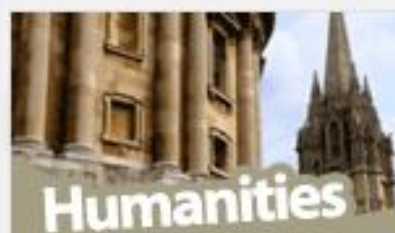

Connecting you to global

humanities research

EXPLORE NOW!

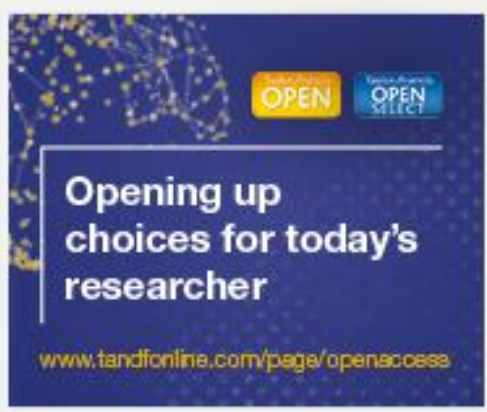




\section{Information for}

Authors

Editors

Librarians

Societies

Help and info

Help

FAQS

Press releases

Contact us

Commercial services
Open access

Overview

Open journals

Open Select

Cogent OA

Connect with Taylor \& Francis

f日e

You

Copyright @ 2017 Informa UK Limited Privacy policy \& cookies Terms \& conditions Accessibility

Registered in England \& Wales No. 3099067

5 Howick Place | London | SW1P 1WG 


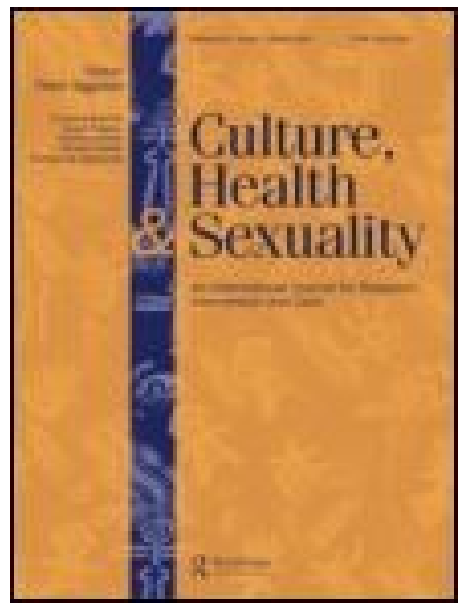

\section{Culture, Health \& Sexuality}

An International Journal for Research, Intervention and Care

Publish open access in this journal

$\sim$ M

Advanced search

Submit an article $\sim$ New content alerts ה RSSEC Citation search

Current issue

In association with the International Association for the Study of Sexuality, Culture \& Society

\section{This journal}

Sample Our

Health and Social Care

journals

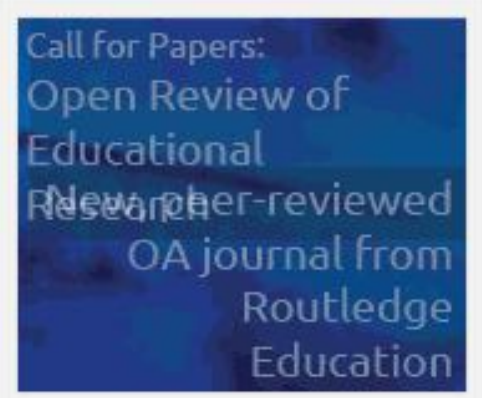




\section{Online archive}

Over 1000 titles, with content from 1996

back to the very

first volume!

\section{Latest articles}

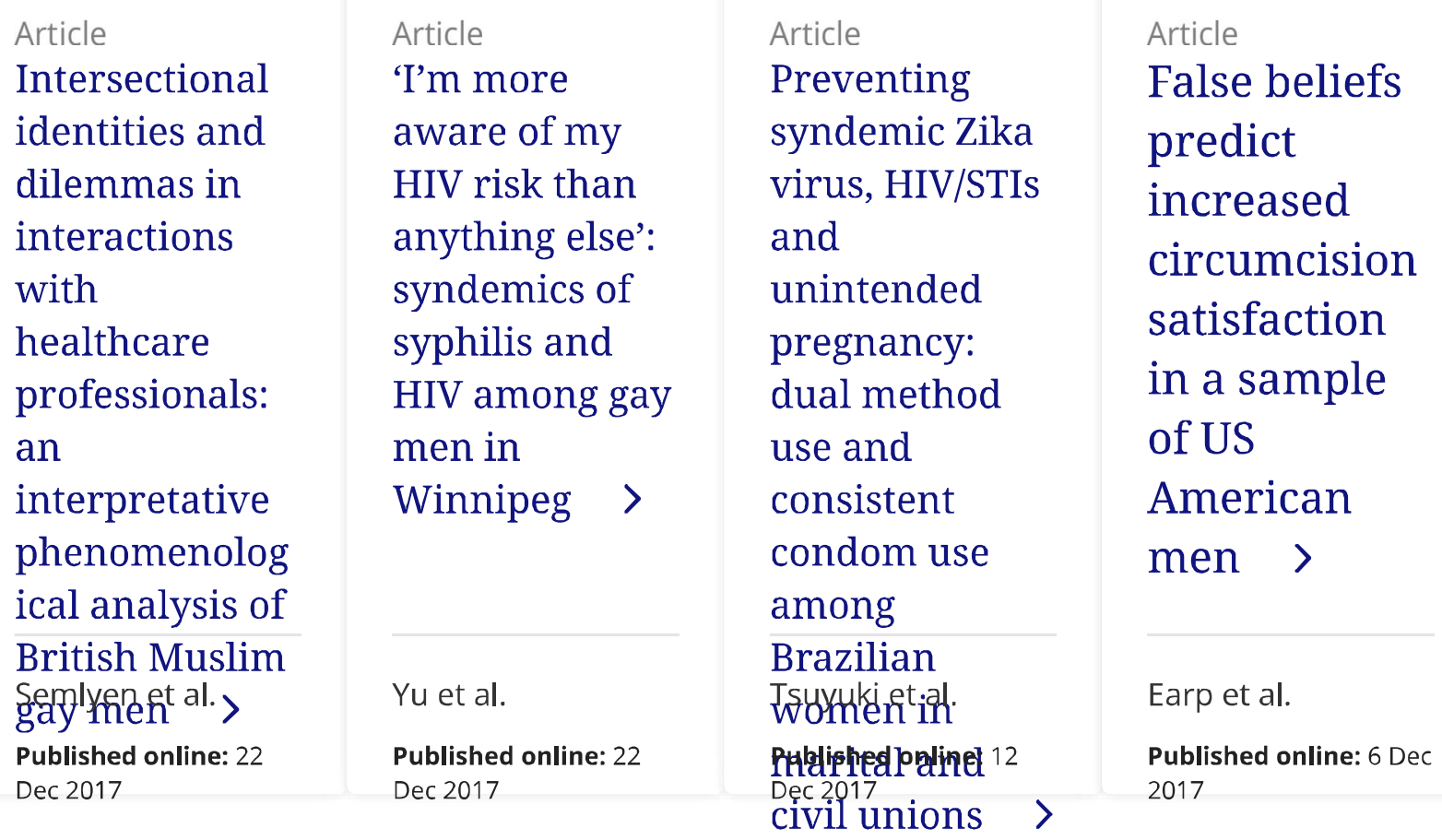

View more>

See all volumes and issues

\begin{tabular}{|c|c|c|c|}
\hline$<$ & Volume 15, 2013 & Vol 14, 2012 & Vol $13,21>$ \\
\hline & $8 \quad 4$ & 3 & \\
\hline
\end{tabular}

Article

Article

Men's experiences of sexuality after cancer: a material discursive intrapsychic approach > 
^submit an article

Published online: 08 May 2013

\begin{tabular}{l|l|l}
577 & 11 & 21 \\
Views & CrossRef citations & Altmetric
\end{tabular}

\title{
Article
}

'Once the stuff's left my body, it's not me': service users' views on unlinked anonymous testing of blood for HIV >

Jessica Datta, Kaye Wellings \& Anthony Kessel

Pages: 896-909

Published online: 10 May 2013

\begin{tabular}{l|l|l}
\hline 139 & 1 & 0 \\
Views & CrossRef citations & Altmetric
\end{tabular}

\section{Article}

'Just Talking About It Opens Your Heart': meaning-making among Black African migrants and refugees living with HIV >

\author{
Mark Henrickson, Derek Brian Brown, Christa Fouché, Cynthia C. Poindexter \& Kay Scott
}

Pages: $910-923$

Published online: 07 May 2013

\begin{tabular}{l|l|l}
\hline 254 & 0 & 1 \\
Views & CrossRef citations & Altmetric
\end{tabular}

\section{Article}

The social construction of AIDS during a time of evolving access to antiretroviral therapy in rural Malawi >

Amy Conroy, Sara Yeatman \& Kathryn Dovel

Pages: 924-937

Published online: 24 May 2013

\begin{tabular}{l|l|l}
\hline 130 & 7 & 1 \\
Views & CrossRef citations & Altmetric
\end{tabular}


^submit an article

Article

Contextual influences on condom use among men who have sex with men in India: subjectivities, practices and risks >

Venkatesan Chakrapani, Paul Boyce, Peter A. Newman \& Ashok Row Kavi

Pages: 938-951

Published online: 19 Jun 2013

\begin{tabular}{l|l|l}
\hline 147 & 12 & 0 \\
Views & CrossRef citations & Altmetric
\end{tabular}

Article

Dismantling reified African culture through localised homosexualities in Uganda >

Stella Nyanzi

Pages: 952-967

Published online: 14 Jun 2013

\begin{tabular}{l|l|l}
\hline 1428 & 19 & 1 \\
Views & CrossRef citations & Altmetric
\end{tabular}

Article

Men who have sex with men in Kisumu, Kenya: support group membership and knowledge of HIV-risk factors >

Dancun O. Okall, Fredrick O. Otieno, Mary Nyikuri, Lisa A. Mills, Felicia Hardnett, Starllone Odero, Kyle Turner \& Deborah A. Gust

Pages: 968-980

Published online: 14 Jun 2013

\begin{tabular}{l|l|l}
189 & 4 & 1 \\
Views & CrossRef citations & Altmetric
\end{tabular}

\section{Article}

Pornography consumption and non-marital sexual behaviour in a sample of young Indonesian university students > 
$\boldsymbol{\Psi}_{\mathrm{s}} \mathrm{ubmit}$ an article

Published online: 20 Jun 2013

\begin{tabular}{l|l|l}
385 & 15 & 6 \\
Views & CrossRef citations & Altmetric
\end{tabular}

\section{Article}

Men and talk about legal abortion in South Africa: equality, support and rights discourses undermining reproductive 'choice' >

Catriona Ida Macleod \& Jateen Hansjee

Pages: 997-1010

Published online: 14 Jun 2013

\begin{tabular}{l|l|l}
\hline 636 & 10 & 1 \\
Views & CrossRef citations & Altmetric
\end{tabular}

Corrigendum

\section{Correction}

Corrigendum >

Page: 1011

Published online: 14 Aug 2013

\begin{tabular}{l|l|l}
\hline 80 & 0 & 0 \\
Views & CrossRef citations & Altmetric
\end{tabular}

\section{Explore}

Most read articles Most cited articles 6 Open access articles 
$\boldsymbol{\tau}_{\mathbf{s}}$ Submit an article

activism,

feminist

discourse

and HIV in

Bangladesh >

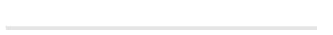

Sultana
Volume 17,2015 - Issue
6
Published online: 15
Jan 2015

Views: 16180

\begin{tabular}{l} 
I ne paraaox \\
of \\
recognition: \\
hijra, third \\
gender and \\
sexual rights \\
in \\
Bangladesh > \\
\\
\hline Hossain \\
Volume 19,2017 - Issue \\
Published online: 12 \\
May 2017
\end{tabular}

Views: 6819

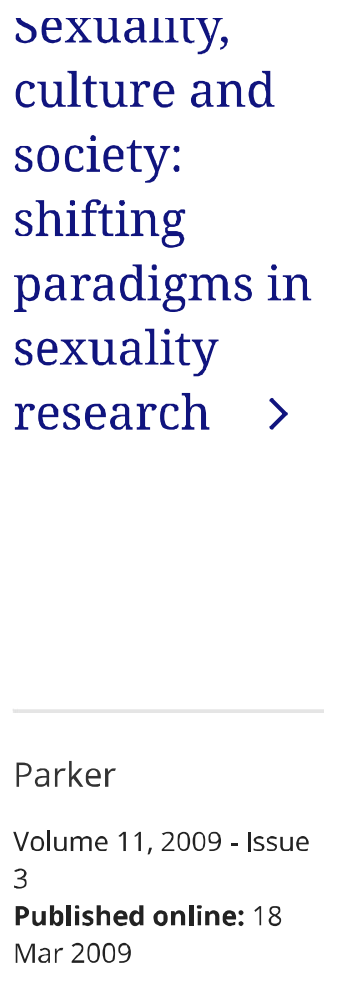

Views: 4926
Heainn

impact of

chest binding

among

transgender

adults: a

community-

engaged,

cross-

sectional

study >

Peitzmeier et al.

Volume 19, 2017 - Issue 1

Published online: 14

Jun 2016

Views: 4731

View more> 


\title{
SJR Scimago Journal \& Country Rank Enter Journal Title, ISSN or Publisher Name
}

Home Journal Rankings Country Rankings Viz Tools Help About Us

\section{Culture, Health and Sexuality}

\author{
Country United Kingdom \\ Subject Area and Medicine \\ Category Public Health, Environmental and Occupational Health \\ Social Sciences \\ Health (social science) \\ H Index \\ Publisher Taylor \& Francis \\ Publication type Journals \\ ISSN 14645351,13691058 \\ Coverage 1999-ongoing \\ Scope Culture, Health \& Sexuality is a leading international environment for the publication of papers \\ in the fields of culture, health and sexuality. The journal is broad and multi-disciplinary in \\ focus, publishing papers on methodology as well as those that are empirical and conceptual \\ in nature. It offers a forum for debates on policy and practice, adopting a practitioner focus \\ where appropriate. Culture, Health and Sexuality takes a genuinely international stance in its \\ consideration of key issues and concerns, as reflected in the composition of the editorial \\ board. (source)
}

\section{Quartiles}

Health (social science)

Public Health, Environmental and Occupational Health

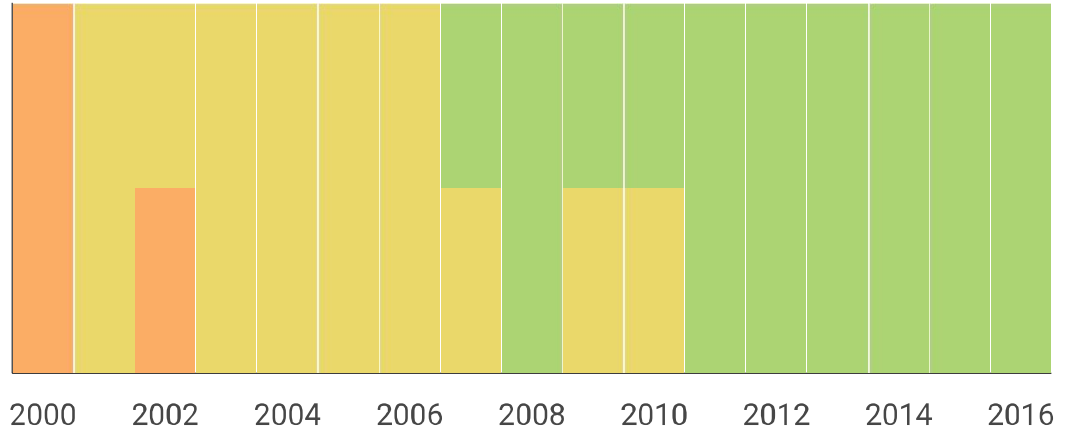

SJR 

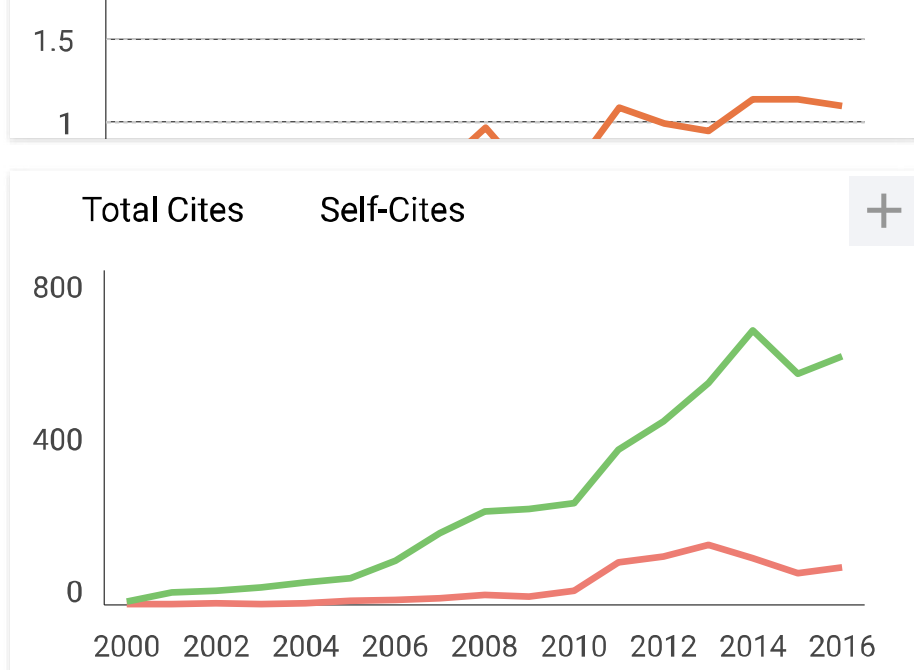

External Cites per Doc Cites per Doc

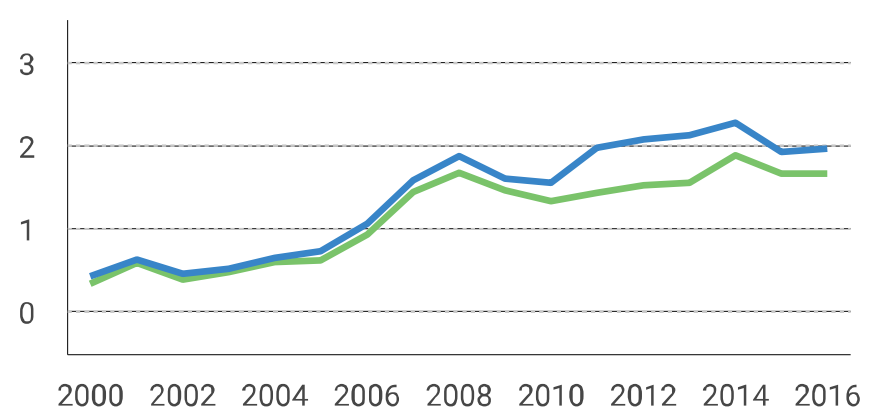

Citable documents Non-citable documents $\quad+$
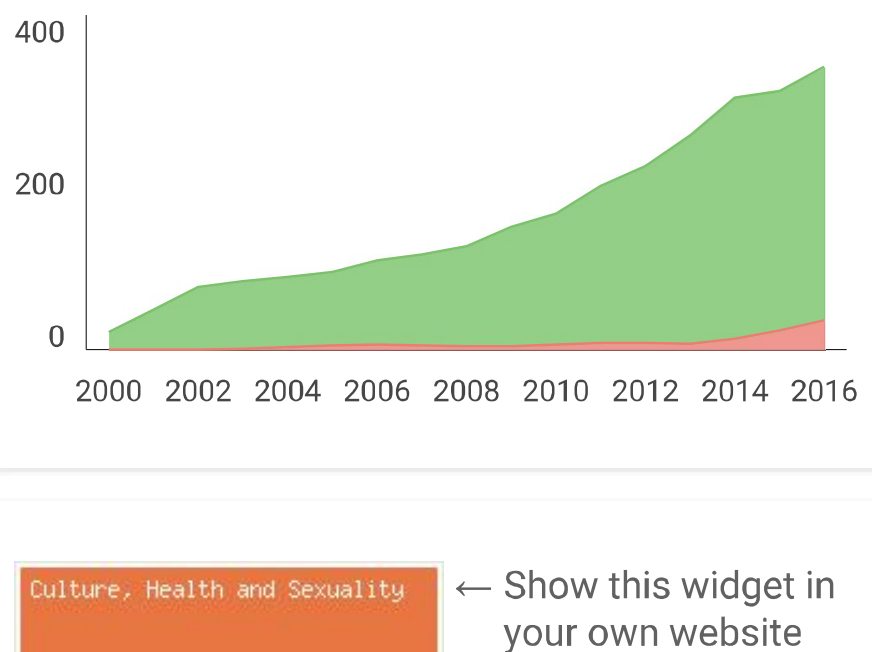

$\leftarrow$ Show this widget in your own website

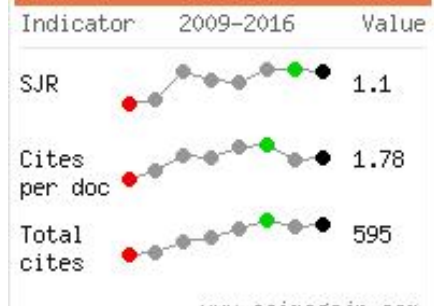

www.scimagojr.com

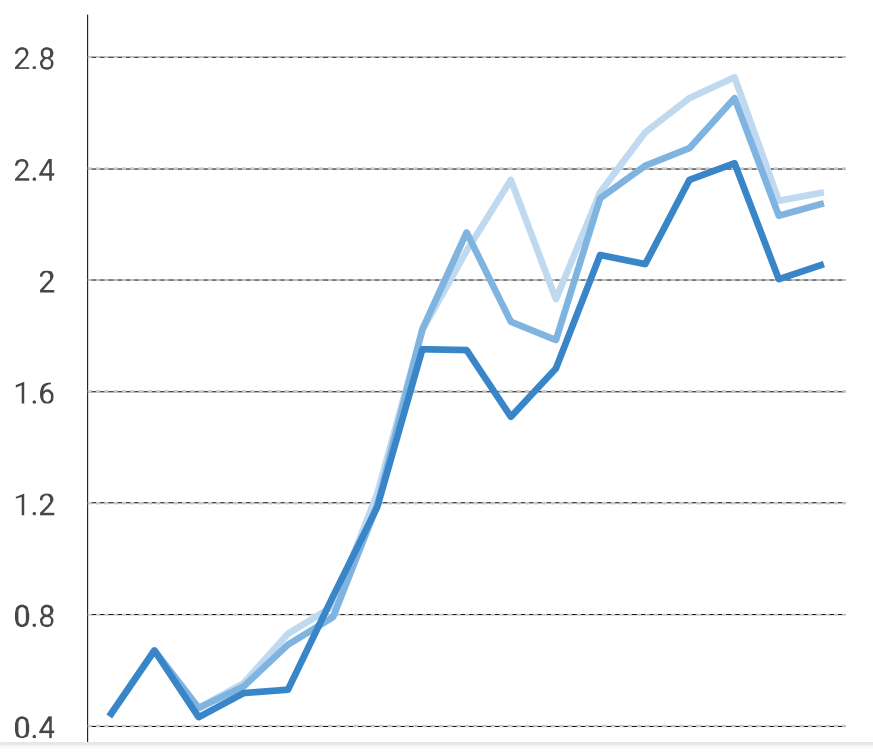

$\%$ International Collaboration

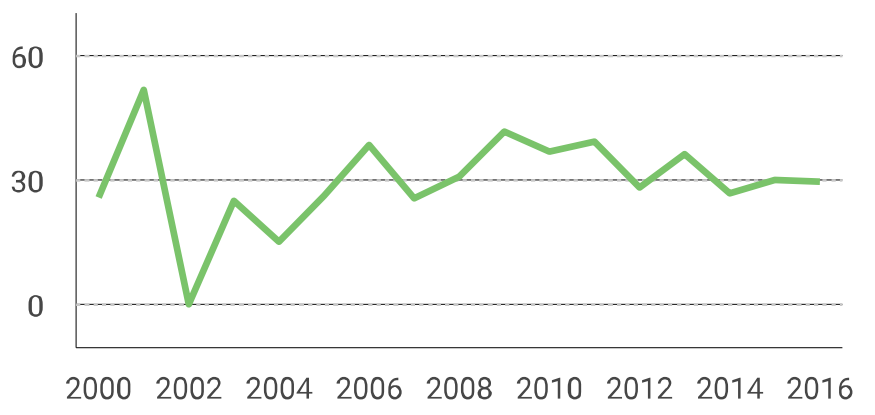

Cited documents Uncited documents

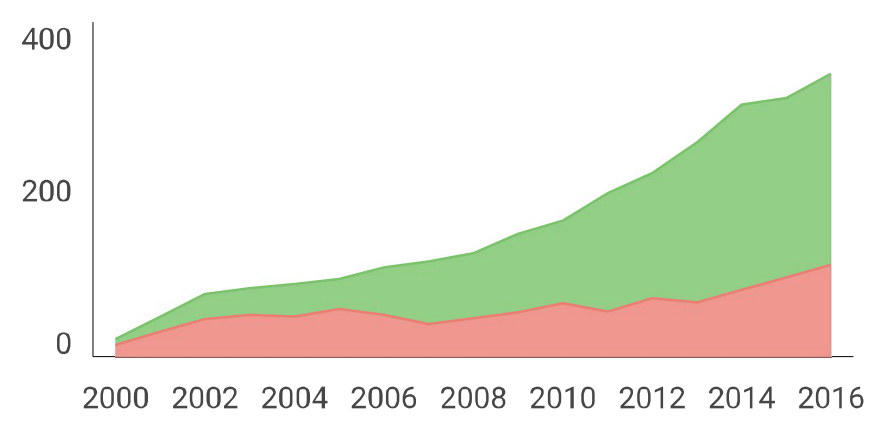




\section{Developed by:}

Powered by:
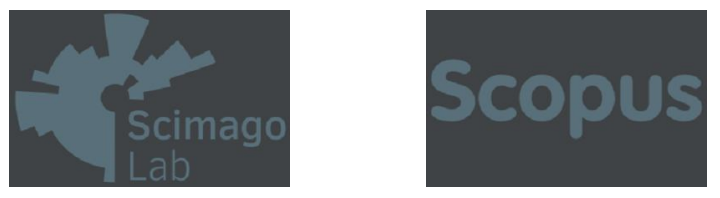

Follow us on Twitter

Scimago Lab, Copyright 2007-2017. Data Source: Scopus ${ }^{\circledR}$

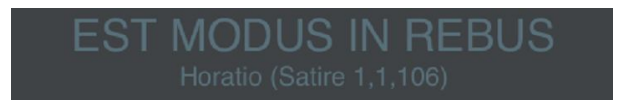

